\title{
Hubungan Karakter Siswa dengan Hasil Belajar Sosiologi Siswa Kelas X dan XI IPS di SMA Negeri 2 Batang Anai Kabupaten Padang Pariaman
}

\author{
Nadya Zahratul Atika ${ }^{1}$, Junaidi Junaidi ${ }^{2}$
}

\author{
${ }^{1.2}$ Universitas Negeri Padang \\ Email: nadyazahratulatika@gmail.com, junaidiunp@,fis.unp.ac.id
}

\begin{abstract}
Abstrak
Tujuan penelitian ini dirancang untuk mengetahui pengaruh karakter peserta didik terhadap hasil belajar peserta didik kelas X dan XI IPS di SMA N 2 Batang Anai Kabupaten Padang Pariaman. Penelitian ini merupakan penelitian expost facto. Populasi penelitian aadalah semua peserta didik kelas $\mathrm{X}$ dan XI IPS di SMA Negeri 2 Batang Anai sebanyak 259 orang peserta didik. Ukuran sample penelitian sebanayak 157 orang peserta didik ditentukan dengan rumus Arikunto, selanjutnya sampel setiap kelas ditentukan dengan teknik Proportional random sampling. Data dikumpulkan dengan angket dan dokumentasi. Analisis data dilakukan dengan analisis deskriptif. Hasil penelitian menunjukkan bahwa terdapat korelasi yang signifikn antara variabel karakter peserta didik dengan hasil belajar sosiologi peserta didik kelas X dan XI IPS di SMA Negeri 2 Batang Anai Kabupaten Padang Pariaman yang dibuktikan dengan koefisien korelasi $\left(\mathrm{r}_{x \gamma}\right) 0.352>r_{\text {tabel }} 0.156$.
\end{abstract}

Kata Kunci: Karakter, Hasil Belajar, Siswa

\section{Abstract}

The purpose of this study was designed to determine the effect of students' character on the learning outcomes of students of class X and XI IPS at SMA N 2 Batang Anai, Padang Pariaman Regency. This research is an ex post facto research. The study population was all students of class X and XI IPS at SMA Negeri 2 Batang Anai as many as 259 students. The sample size of the study was 157 students determined by the Arikunto formula, then the sample for each class was determined by the Proportional random sampling technique. Data collected by questionnaire and documentation. Data analysis was performed by descriptive analysis. The results showed that there was a significant correlation between student character variables and sociology learning outcomes of students of class X and XI IPS in SMA An 2 Batang Anai, Padang Pariaman, as evidenced by the correlation coefficient $\left(r_{x_{1}}\right) 0.352>r_{-}$table 0.156.

Keywords: Character, Learning Outcomes, Students

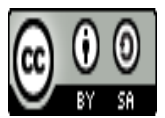


Hasil belajar merupakan gambaran tentang bagaimanapeserta didik memahamai materi yang disampaikan oleh guru. Untuk mengetahui hasil belajar seseorang dapat kita lihat dengan cara tes dan pengukuran.Hasil belajar merupakan suatu bentuk perubahan perilaku yang relatif menetap dalam diri seseorang sebagai akibat dari interkasi seseorang dengan lingkungan sekitarnya(Yani, 2017). Hasil belajar adalah ukuran tingkat keberhasilan yang telah diperoleh olehpeserta didik berdasarkan pengalaman yang di dapatkan setelah dilakukan evaluasi berupa tes dan biasanya diwujudkan dengan nilai tertentu serta menyebabkan terjadinya perubahan kognitif, afektif, maupun psikomotorik (Harisandy, 2015). Dalam sistem pendidikan nasional, tujuan pendidikan menggunakan klasifikasi hasil belajar dari Benyamin Bloom yang secara garis besar membaginya menjadi tiga ranah, yakni : ranah kognitif, ranah afekrif dan ranah psikomotor (Sudjana, 2011). Hasil belajar yang dicapai oleh seorang peserta didik adalah hasil dari interaksi antara bermacam faktor yang mempebaruhinya baik dari dalam dan dari luar diri individunya (Hiadaytullah, 2011).Semua mata pelajaran menjadikan ketiga aspek tersebut sebagai tolak ukur untuk menilai hasil belajar. Prioritas materi dan hasil belajar tidak sama setiap mata pelajaran begitu juga sosiologi. Pada mata pelajaran yang bersifat teknis, maka materi dan hasil belajar lebih banyakk menemukan aspek psikomotor. Sedangkan mata pelajaran sosiologi lebih banyak menekankan pada aspek kognitif. Sosiologi merupakan salah satu mata pelajaran pada lembaga pendidikan sekolah Menengah Atas (SMA) memiliki peran yang sangat penting untuk mengembangkan pemehaman siswa terhadap konsep dan fenomena sosial, dengan adanya pemehaman peserta didik diharapkan mempu untuk menghadapi dan berbagai masalah dalam kehidupan sehari-hari, selain itu dengan tercapainya pemahaman peserta didik mempu mempunyai hasil belajar yang disesuaikan.(Indrahadi, 2017). Peserta didik diharapkan manguasai materi pembelajaran yang banyak bersifat konsep sehingga peserta didik dapat mencapai hasil belajar yang diinginkan. Hasil belajr semua peserta didik harus mencapai Kriteria Ketuntasan Minimal (KKM). Besarana KKM sesuai dengan sekolah masing-masing. Di SMA Negeri 2 Batang Anai KKM mata pelajaran sosiologi yakni 78. Namun kenyataan hasil belajar sosiologi peserta didik di SMA Negeri 2 Batang Anai ada sebagian yang dibawah KKM yang ditetapkan oleh sekolah yakni 78, khususnya pada kelas X dan XI IPS dapat dilihat dari abel dibawah ini:

\section{Tabel 1. Hasil Belajar Sosiologi Peserta didik kls X dan XI IPS SMA N 2 Batang Anai}

\begin{tabular}{|c|c|c|c|c|c|}
\hline \multirow[t]{2}{*}{ No } & \multirow[t]{2}{*}{ Kelas } & \multicolumn{2}{|c|}{ Jumlah Peserta Didik } & \multirow[t]{2}{*}{ KKM } & \multirow[t]{2}{*}{ Nilai Rata-rata } \\
\hline & & Laki-laki & Perempuan & & \\
\hline 1. & X IPS 1 & 12 & 23 & 78 & 63.37 \\
\hline 2. & X IPS 2 & 12 & 23 & 78 & 62.88 \\
\hline 3. & X IPS 3 & 15 & 17 & 78 & 63,71 \\
\hline 4. & X IPS 4 & 19 & 14 & 78 & 63.35 \\
\hline 5. & XI IPS 1 & 15 & 17 & 78 & 72.68 \\
\hline 6. & XI IPS 2 & 12 & 17 & 78 & 67.06 \\
\hline 7. & XI IPS 3 & 13 & 20 & 78 & 66.25 \\
\hline \multirow[t]{2}{*}{8.} & XI IPS 4 & 15 & 15 & 78 & 63.43 \\
\hline & Jumlah & \multicolumn{4}{|c|}{259} \\
\hline
\end{tabular}

Sumber: Pengolahan Data Primer 2019

Berdasarkan data di atas terlihat bahwa hasil belajar mata pelajaran sosiologi peserta didik kelas X dan XI di SMA Negeri 2 Batang Anai Kabupaten Padang Pariaman belum mencapai standar yang telah ditetapkan dalam Kriteria Ketuntasan Minimal (KKM). Nilai rata-rata pada 
kisaran 60 sedangkan KKM yang ditetapkan sekolah adalah 78. Menurut Slameto (Nina Isnawati, 2012) mengatakan bahwa hasil belajar siswa yang rendah dipengaruhi oleh dua faktor yaitu faktor internal (dari dalam diri peserta didik) yakni kesehatan, cacat tubuh, perhatian, minat, bakat, motivasi, karakteristik dan faktor eksternal (dari luar diri peserta didik) yakni: cara orang tua mendidik anak, suasana rumah, keadaan ekonomi keluarga, perhatian orang tua, metode mengajar, kurikulum, relasi guru dan peserta didik, relasai antar peserta didik.

Berdasarkan pendapat diatas salah satu faktor yang mempengaruhi hasil belajar peserta didik adalah faktor internal yaitu karakter peserta didik. Dari data yang peneliti peroleh dari guru BK belum tertanamnya nilai karakter pada peserta didik yang paling menonjol yaitu nilai karakter disiplin oleh peserta didik kelas X dan XI IPS dimana selama pembelajaran Juli hingga Desember terdapat jumlah dari seluruh peserta didik kelas X IPS yang tidak hadir tanpa keterangan Absen sebnayak 1372 hari, Izin sebanyak 30 hari, terlambar sebanyak 415 hari, sakit sebnayak 22 hari, dan cabut 2 hari Selain mendapat data drai guru BK, peneliti juga mendapatkan data dari angket yang peneliti sebar kepada kelas X dan XI IPS di SMA Negeri 2 Batang Anai. Selain itu melalui observasi yang dilakukan selama melakukan PPL pada bulan Juli - Desember di SMA Negeri 2 Batang Anai. Indikasi menunjukkan bahwa nilai karakter di SMA Negeri 2 Batang Anai kelas X dan XI IPS didapat data sebagai berikut : 1) terdapat peserta didik yang masih terlambat masuk sekolah atau masuk kelas setelah jam istrirahat (nilai disiplin), 2) terdapat peserta didik yang mencontek saat ujian ( nilai jujur), 3) terdapat peserta didik tidak memanfaatkan sumber belajar buku, perpustakaan, internet (rasa ingin tahu ) dan 4) terdapat peserta didik membuat latihan tidak sesuai dengan yang ditentukan (tanggung jawab).

Selain itu peneliti juga mendapatkan data dari angket yang peneliti sebar kepada peserta didik kelas X dan XI IPS di SMA Negeri 2 Batang Anai, dimana hasil angket yang diperoleh yakni : 1.) Nilai disiplin $80 \%$ belum tertanam, 2.) Kerja keras $80 \%$ belum tertanam, 3.) Demokrasi $80 \%$ belum tertanam, 4.) Rasa ingin tahu $80 \%$ belum tertanam, 5.) Cinta tanah air $80 \%$ belum tertanam, 5.) Menghargai prestasi $80 \%$ belum tertanam, 6.) Peduli lingkungan $80 \%$ belum tertanam, 7.) Peduli lingkungan $80 \%$ belum tertanam, 8.) Peduli sosial $80 \%$ belum tertanam, dan 9.)Tanggung jawab $80 \%$ belum tertanam.Setelah melihat darai data yang didapatkan, peneliti menyimpulkan bahwa peserta didik kelas X dan XI IPS di SMA Negeri 2 Batang Anai belum tertanamnya nilai karakter dengan baik. Seharusnya peseta didik mampu menaati peratuaran dan tata tertib yang ada di lingkungan sekolah, supaya perserta didik dapat membentuk karakter yang disiplin dan bertanggu jawab (Setiawan \& Sylvia, 2013).

Karakter berasal dari Bahasa Yunani memiliki arti "to mark" ( menandai) dan fokusnya pada bagimana seseorang manerapkan nilai kebaikan tersebut dalam bertindak dan berperilaku dalam kehidupan sehari-hari.Maka dari itu seseorang yang memiliki perilaku jujur sering dikatakan orang baik dan seseorang yang tidak berperilaku jujur, kejam sering dikatakan orang tersebut memiliki karakter jelek (Elfendri, 2007). Karakter mengacu pada serangkaian sikap dan perilakuseperti keinginan untuk melakukan hal yang terbaik, jujur dan bertanggung jawab, mempertahankan prinsip-prinsip moral dalam situasi penuh keadilan, kecakapan interpersonal dan emosional yang memungkinkan seseorang berinteraksi secara efektif dalam berbagai keadaan, serta komitmen untuk ikut serta berperan dengan komunitas dan masyarakat (Assidiqi, 2015). Karakter peserta didik mencerminkan kepribadian peserta didik seperti moral yang dibentuk dari lahir keluarga, dan lingkungan sekitar, karakter menjadi ciri khas pembeda seseorang. (Anggrianto Ardani Putra, 2012) ada 18 kerakter yang tertanam dalam diri peserta didik untuk membangun karakter tersebut menurut kemantrian pendidikan nasional. 18 nilai karakter tersebut yaitu 1.agamais, 2. kejujuran, 3. sikap toleransi, 4. disiplin, 5. kerjakeras, 6. kreatif, 7. sikap mandiri, 8. demokratis, 9. rasa ngin tahu yang besar, 10. semangat kebangsaan yang tingga, 11. cinta tanah air, 12. prestasi, 13. bersahabat, 14. damai, 15. suku membaca, 16. lingkungan sekitar, 17. sosial, 18. tanggung jawab. (Sahlan \& Prasetyo, 2012). karakter yang kurang tertanam dengan baik dapat mempengaruhi pola perilaku peserta didik dimasa yang akan datang. Karakter peserta didik merupakan kepribadian yang dimiliki oleh seorang peserta didik, ditunjukkan oleh perilaku dan dan sikap jujur yang harus ada pada peserta didik agar dapat

Jurnal Sikola: Jurnal Kajian Pendidikan dan Pembelajaran Vol. 1, No. 1, Th. 2019 
Hubungan Karakter Peserta didik dengan Hasil Belajar Sosiologi Peserta didik Kelas X dan XI IPS di SMA Negeri 2 Batang Anai Kabupaten Padang Pariaman dipercaya melalui perkataan tindakan dan tanggung jawab.(Totok, 2014). Karakter seseorang merupakan sikap yang dapat diandalkan untuk menghadapi situasi dalam kehidupan dan dapat bekerjasama serta hubungan dengan tuhandiri sendiri dan lingkungan. (Cahyadi, 2018).

Data krakter dan hasil belajar peserta didik di atas menimbulkan ketertarikan bagi peneliti untuk mengungkapnya. Adakah kiranya kaitan antara rendahnya hasil belajar peserta didik dengan karakter peserta didik tersebut. Tujuan penelitian ini adalah untuk mencari tahu atau menganalisis tentang adakah keterkaitan antara karakter peserta didik dengan hasil belajr peserta didik.

\section{Metode Penelitian}

Pendekatan yang digunakan kuantitatif termasuk jenis penelitian korelasional dimana peneliti menggunakan statistik korelasional untuk menggambarkan dan mengukur tingkat atau asosiasi (hubungan antara dua variabel atau lebih dalam rangkaian skor (Creswell, 2014). Jenis penelitian expost-facto memiliki tujuan penyebab yang memungkinkan perubahan perilaku, gejala atau fenomena yang disebabkan oleh suatu peristiwa, perilaku, gejala atau fenomena yang disebabkan oleh suatu peristiwa, perilaku atau hal-hal yang menyebabkan perubahan pada variabel bebas secara keseluruhan yang sudah terjadi (Widarto, 2013). Teknik pengumpulan data yang dipakai adalah proportional random sampling dengan jumlah sampel 157 orang. Cara pengumpulan data menggunakan angket dan dokumentasi.

\section{Hasil dan Pembahasan}

Pada Penelitian ini karakter siswa ditetapkan sebagai variabel bebas (indipenden variabel) dan hasil belajar ditetapkan sebagai variabel terikat (dependen variabel). Sampel penelitian berjumlah 157 orang siswa kelas X dan XI IPS SMA Negeri 2 Batang Anai Kabupaten Padang Pariaman. Setelah sampel ditetapkan, kemudian dilaksanakan pendataan data tentang karakter siswa dengan 18 indikator yaitu : religius, jujur, toleransi, disiplin, kerja keras, kreaktif, mandiri, demokratis, rasa ingin tahu, semangat kebangsaan, cinta tanah air, menghargai prestasi, bersahabat/komunikatif, cinta damai, gemar membaca, peduli lingkungan, peduli sosial, dan tanggung jawab. Berdasarkan pengukuran, dilaksankan uji normalitas dan uji linearitas. Hasil didapatkan bahwa data berdistrubusi normal dan linear. Peneltian menggunakan analisis korelasi Product Momen. Berdasarkan hasil penelitian yang peneliti dapatkan bahwa Berdasarkan uji korelasi terdapat hubungan karakter siswa dengan nilai belajar siswa kels X dan XI IPS di SMA N 2 Batang Anai Pada Tahun Ajaran 2019/2020, dalam perolehan hasil analisis Person correlation didapatkan nila $\mathrm{r}$ hitung 0.352 dan $\mathrm{r}$ tabel 0.156 , yang berarti niali $\mathrm{r}$ hitung lebih besar dari pada nilai $r$ tabel sehingga dapat dikatakan adanya korelasi antara karakter siswa dengan hasil belajar siswa. Uji korelasi dari masing-masing indikator menunjukkan tidak semua indikator berkorelasi dengan hasil belajar. Untuk lebih jelasnya:

Tabel 2. Hasil Uji Korelasi Indikator Karakter Siswa dengan Hasil Belajar Siswa

\begin{tabular}{lllcc}
\hline No. & Indikator Karakter Siswa & r hitung & r tabel & Keterangan \\
\hline 1. & Religius & 0.245 & 0.156 & Berkorelasi \\
\hline 2. & Jujur & 0.212 & 0.156 & Berkorelasi \\
\hline 3. & Toleransi & 0.109 & 0.156 & Tidak Berkorelasi \\
\hline 4. & Disiplin & 0.237 & 0.156 & Berkorelasi \\
\hline 5. & Kerja Keras & 0.186 & 0.156 & Berkorelasi \\
\hline 6. & Kreaktif & 0.344 & 0.156 & Berkorelasi \\
\hline 7. & Mandiri & 0.049 & 0.156 & Tidak Berkorelasi \\
\hline 8. & Demokratis & 0.255 & 0.156 & Berkorelasi \\
\hline 9. & Rasa Ingin Tahu & 0.158 & 0.156 & Berkorelasi \\
\hline
\end{tabular}

Jurnal Sikola: Jurnal Kajian Pendidikan dan Pembelajaran Vol. 1, No. 1, Th. 2019 
Nadya Zahratul Atika, Junaidi

Hubungan Karakter Peserta didik dengan Hasil Belajar Sosiologi Peserta didik

Kelas X dan XI IPS di SMA Negeri 2 Batang Anai Kabupaten Padang Pariaman

\begin{tabular}{llccc}
\hline 10 & Semangat Kebangsaan & 0.195 & 0.156 & Berkorelasi \\
\hline 11. & Cinta Tanah Air & 0.192 & 0.156 & Berkorelasi \\
\hline 12. & Menghargai Prestasi & 0.196 & 0.156 & Berkorelasi \\
\hline 13. & Bersahabat/Komunikatif & 0.200 & 0.156 & Berkorelasi \\
\hline 14. & Cinta Damai & 0.167 & 0.156 & Berkorelasi \\
\hline 15. & Gemar Membaca & 0.216 & 0.156 & Berkorelasi \\
\hline 16. & Peduli Lingkungan & 0.231 & 0.156 & Berkorelasi \\
\hline 17. & Peduli Sosial & 0.282 & 0.156 & Tidak Berkorelasi \\
\hline 18. & Tanggung Jawab & 0.069 & 0.156 & \\
\hline
\end{tabular}

Sumber: Pengolahan Data Primer, 2019

Dari tabel diatas dapat dilihat bahwa karakter siswa, dari 18 indikator terdapat 3 indikator yang tidak berkorelasi dan 15 indikator terdapat korelasi. yang dibuktikan dengan nilai $\mathrm{r}$ hitung lebih besar dari $\mathrm{r}$ tabel. Jelasnya dapat dipaparkan sebagai berikut:

\section{Nilai Karakter Religius}

Indikator yang pertama dari karakter siswa adalah nilai karakter religius. Nilai karakter religius ini memiliki hubungan yang signifikan dari hasil belajar siswa yang diperoleh $\mathrm{r}$ hitung $=$ $0.224>\mathrm{r}$ tabel 0.158 . Artinya nilai karakter religius memiliki korelasi yang sifnifikan dengan hasil belajar siswa.

\section{Nilai Karakter Jujur}

Indikator yang kedua dari karakter siswa adalah nilai karakter Jujur. Nilai karakter jujur ini memiliki hubungan yang signifikan dari hasil belajar siswa yang diperoleh $\mathrm{r}$ hitung $=0.212>$ $\mathrm{r}$ tabel 0.158 . Artinya nilai karakter jujur memiliki korelasi yang sifnifikan dengan hasil belajar siswa.

\section{Nilai Karakter Toleransi}

Indikator yang ketiga dari karakter siswa adalah nilai karakter toleransi. Nilai karakter toleransi ini tidak memiliki hubungan yang signifikan dari hasil belajar siswa yang diperoleh $\mathrm{r}$ hitung $=0.109<\mathrm{r}$ tabel 0.158 . Artinya nilai karakter toleransi tidak memiliki korelasi yang sifnifikan dengan hasil belajar siswa.

\section{Nilai Karakter Disiplin}

Indikator yang keempat dari karakter siswa adalah nilai karakter disiplin. Nilai karakter disiplin ini memiliki hubungan yang signifikan dari hasil belajar siswa yang diperoleh $\mathrm{r}$ hitung $=$ $0.237>\mathrm{r}$ tabel 0.158 . Artinya nilai karakter disiplin memiliki korelasi yang sifnifikan dengan hasil belajar siswa. Disiplin berguna untuk menyadarkan seseorang bahwa dirinya perlu menghargai orang lain dengan cara mentaati dan mematuhi peraturan yang berlaku, sehingga tidak akan merugikan pihak lain dan hubungan antar sesama akan menjadi baik dan lancar. (Sylvia, 2013)

\section{Nilai Karakter Kerja Keras}

Indikator yang kelima dari karakter siswa adalah nilai karakter kerja keras. Nilai karakter kerja keras ini memiliki hubungan yang signifikan dari hasil belajar siswa yang diperoleh $\mathrm{r}$ hitung $=0.218>\mathrm{r}$ tabel 0.158 . Artinya nilai karakter kerja keras memiliki korelasi yang sifnifikan dengan hasil belajar siswa. 
Indikator yang keenam dari karakter siswa adalah nilai karakter kreaktif. Nilai karakter kreaktif ini memiliki hubungan yang signifikan dari hasil belajar siswa yang diperoleh $\mathrm{r}$ hitung $=$ $0.344>\mathrm{r}$ tabel 0.158 . Artinya nilai karakter kreaktif memiliki korelasi yang sifnifikan dengan hasil belajar siswa.

\section{Nilai Karakter Mandiri}

Indikator yang ketujuh dari karakter siswa adalah nilai karakter mandiri. Nilai karakter mandiri ini tidak memiliki hubungan yang signifikan dari hasil belajar siswa yang diperoleh $\mathrm{r}$ hitung $=0.049<\mathrm{r}$ tabel 0.158. Artinya nilai karakter mandiri tidak memiliki korelasi yang sifnifikan dengan hasil belajar siswa.

\section{Nilai Karakter Demokratis}

Indikator yang delapan dari karakter siswa adalah nilai karakter demokratis. Nilai karakter demokratis ini memiliki hubungan yang signifikan dari hasil belajar siswa yang diperoleh $\mathrm{r}$ hitung $=0.259>\mathrm{r}$ tabel 0.158 . Artinya nilai karakter demokratis memiliki korelasi yang sifnifikan dengan hasil belajar siswa.

\section{Nilai Karakter Rasa Ingin Tahu}

Indikator yang sembilan dari karakter siswa adalah nilai karakter rasa ingin tahu. Nilai karakter rasa ingin tahu ini memiliki hubungan yang signifikan dari hasil belajar siswa yang diperoleh $\mathrm{r}$ hitung $=0.159>\mathrm{r}$ tabel 0.158 . Artinya nilai karakter rasa ngin tahu memiliki korelasi yang sifnifikan dengan hasil belajar siswa.

\section{Nilai Karakter Semangat Kebangsaan}

Indikator yang sepuluh dari karakter siswa adalah nilai karakter semangat kebangsaan. Nilai karakter semangat kebangsaan ini memiliki hubungan yang signifikan dengan hasil belajar siswa yang diperoleh dengan nilai $\mathrm{r}$ hitung $=0.192>\mathrm{r}$ tabel 0.158 . Artinya nilai karakter semangat kebangsaan memiliki korelasi yang sifnifikan dengan hasil belajar siswa.

\section{Nilai Karakter Cinta Tanah Air}

Indikator yang sebelas dari karakter siswa adalah nilai karakter cinta tanah air. Nilai karakter cinta tanah air ini memiliki hubungan yang signifikan dari hasil belajar siswa yang diperoleh $\mathrm{r}$ hitung $=0.192>\mathrm{r}$ tabel 0.158 . Artinya nilai karakter cinta tanah air memiliki korelasi yang sifnifikan dengan hasil belajar siswa.

\section{Nilai Karakter Menghargai Prestasi}

Indikator yang dua belas dari karakter siswa adalah nilai karakter menghargai prestasi. Nilai karakter menghargai prestasi ini memiliki hubungan yang signifikan dari hasil belajar siswa yang diperoleh $\mathrm{r}$ hitung $=0.196>\mathrm{r}$ tabel 0.158 . Artinya nilai karakter menghargai prestasi memiliki korelasi yang sifnifikan dengan hasil belajar siswa.

\section{Nilai Karakter Bersahahat/Komunikatif}

Indikator yang tiga belas dari karakter siswa adalah nilai karakter bersahabat/ komunikatif. Nilai karakter bersahabat/komunikatif ini memiliki hubungan yang signifikan dari hasil belajar siswa yang diperoleh $\mathrm{r}$ hitung $=0.200>\mathrm{r}$ tabel 0.158 . Artinya nilai karakter bersahabat/ komunikatif memiliki korelasi yang sifnifikan dengan hasil belajar siswa. 
Nilai Karakter Cinta Damai

Kelas X dan XI IPS di SMA Negeri 2 Batang Anai Kabupaten Padang Pariaman

Indikator yang empat belas dari karakter siswa adalah nilai karakter cinta damai. Nilai karakter cinta damai ini memiliki hubungan yang signifikan dari hasil belajar siswa yang diperoleh dengan yang sifnifikan dengan hasil belajar siswa.

\section{Nilai Karakter Gemar Membaca}

Indikator yang lima belas dari karakter siswa adalah nilai karakter gemar membaca. Nilai karakter gemar membaca ini memiliki hubungan yang signifikan dari hasil belajar siswa yang diperoleh $\mathrm{r}$ hitung $=0.216>\mathrm{r}$ tabel 0.158 . Artinya nilai karakter gemar membaca memiliki korelasi yang sifnifikan dengan hasil belajar siswa.

\section{Nilai Karakter Peduli Lingkungan}

Indikator yang enam belas dari karakter siswa adalah nilai karakter peduli lingkungan. Nilai karakter peduli lingkungan ini memiliki hubungan yang signifikan dari hasil belajar siswa yang diperoleh $\mathrm{r}$ hitung $=0.231>\mathrm{r}$ tabel 0.158 . Artinya nilai karakter peduli lingkungan memiliki korelasi yang sifnifikan dengan hasil belajar siswa.

\section{Nilai Karakter Peduli Sosial}

Indikator yang tujuh belas dari karakter siswa adalah nilai karakter peduli sosial. Nilai karakter peduli sosial ini memiliki hubungan yang signifikan dari hasil belajar siswa yang diperoleh $\mathrm{r}$ hitung $=0.282>\mathrm{r}$ tabel 0.158 . Artinya nilai karakter peduli sosial memiliki korelasi yang sifnifikan dengan hasil belajar siswa.

\section{Nilai Karakter Tanggung Jawab}

Indikator yang delapan belas dari karakter siswa adalah nilai karakter tanggung jawab. Nilai karakter tanggung jawab ini tidak memiliki hubungan yang signifikan dari hasil belajar siswa yang diperoleh $\mathrm{r}$ hitung $=0.065<\mathrm{r}$ tabel 0.158 . Artinya nilai karakter tanggung jawab tidak memiliki yang sifnifikan dengan hasil belajar siswa.

Teori yang digunakan untuk menganalisa Hubungan karakter siswa dengan hasil belajar siswa yaitu teori behavioristik. Teori behavioristik merupakan sebuah aliran dalam teori belajar yang sangat menekankan pada perlunya tingkah laku yang dapat diamati (Nahar, 2016). Menurut teori Behavioristik merupakan perubahan perilaku sebagai akibat adanya interaksi antara stimulus dan respon. Seorang dianggap telah belajar sesuatu jika ia dapat menunjukkan perilakunya. Teori ini mengutamakan pengukuran, sebab pengukuran merupakan suatu hal yang penting untuk melihat terjadinya perubahan tingkah laku tersebut.

\section{Kesimpulan}

Secara umum terdapat korelasi yang signifikan antar variabel karakter siswa dengan hasil belajar sosiologi siswa kelas X dan XI IPS di SMA Negeri 2 Batang Anai Kabupaten Padang Pariaman yang dibuktikan denga koefeisien korelasi $\left(\mathrm{r}_{x \gamma}\right) \quad 0.352>$ rtabel 0.156 . Uji korelasi masing-masing indikator karakter siswa dengan hasil belajar sosiologi siswa menunjukkan bahwa dari 18 indikator terdapat 3 indikator yang tidak memiliki hubungan korelasi dengan hasil belajar dan 15 indikator memiliki hubungan korelasi yang signifikan.

\section{Daftar Pustaka}

Anggrianto Ardani Putra, N. (2012). Hubungan Karakter Siswa dengan Prestasi Belajar Siswa Kelas XI Program Keahlian Teknik Instalasi Tenaga Listrisk (TITL) di Sma Negeri 2 Yogyakarta. Экономика Региона, 10(9), 32.

Assidiqi, H. (2015). Membentuk karakter peserta didik melalui model pembelajaran search,

Jurnal Sikola: Jurnal Kajian Pendidikan dan Pembelajaran Vol. 1, No. 1, Th. 2019 
Nadya Zahratul Atika, Junaidi Hubungan Karakter Peserta didik dengan Hasil Belajar Sosiologi Peserta didik Kelas X dan XI IPS di SMA Negeri 2 Batang Anai Kabupaten Padang Pariaman solve, create, and share. Math Didactic: Jurnal Pendidikan Matematika, 1(1), 45-55. https://doi.org/10.33654/math.v1i1.94

Cahyadi, A. N. (2018). Pembentukan Karakter Siswa Melalui Program Boarding School di SMP Islam Terpadu Ar-Risalah Kebumen Tahun 2017.

Creswell, W. J. (2014). Penelitian Kualitatif dan Desain Riset. Jakarta: PT Bina Aksara.

Elfendri. (2007). Pendidikan karakter strategi mendidik anak di zaman global. Jakarta: Grasindo.

Harisandy, R. (2015). Peningkatan Hasil Belajar Siswa Kelas Xi Pada Mata Pelajaran Pengendali Daya Tegangan Rendah Smk 1 Sedayu Melalui Model Kooperatif Tipe Gi (Group Investigation). 1-117.

Hiadaytullah, S. (2011). Meningkatkan Belajar Siswa Melalui Strtegi Pembelajaran Kooperatif Teknik Jigsaw Pada Konsep Hidrokarbon: Penelitian Tindakan Kelas (Classroom Action Research).

Indrahadi, deri J. (2017). Upaya Meningkatkan Kemampuan Peserta Didik Berfikir Kritis Melalui Penerapkan Strategi Pembelajaran Berbasis Masalah Pada Pembelajaran Sosiologi Kelas XI IPS SMA Negri 1 Pariman. Perspektif, 4, 22.

Nahar, N. I. (2016). Penerapan Teori Belajar Behavioristik dalam Proses Pembelajaran. Jurnal Ilmu Pengetahuan Sosial, 1(1), 3. https://doi.org/10.1111/j.1365-2141.1992.tb08137.x

Nina Isnawati, D. S. (2012). 1 BANJARNEGARA. Jurnal Pendidikan Akuntansi Indonesia, X(1), 66-77.

Sahlan, A., \& Prasetyo. (2012). Desain Pembelajaran BerbasisKarakter. Yogyakarta: Ar-Ruzz Media.

Setiawan, I., \& Sylvia, I. (2013). Hubungan Antara Konformitas Kelompok Teman Sebaya dengan Disiplin Siswa SMA Negeri 5 Padang. 17(1), 101-113.

Sudjana, nana. (2011). Penilaian Hasil Proses Belajar Mengajar. Bandung: PT. Remaja Rosdakarya.

Sylvia, I. (2013). Jurnal Diakronika, Vol XII, No 1 Th 2012. Diakronika, Vol XII, No 1 Th 2012, XII(1), 101-113. https://doi.org/10.31227/osf.io/tm5ba

Totok, G. (2014). Pengaruh Karakter Siswa Dan Hasil Belajar Mata Pelajaran Produktif Terhadap Kesiapan Kerja Siswa Kelas Xii Jurusan Teknik Kendaraan Ringan di SMK Muhammadiyah 1 Bantul.

Widarto. (2013). Penelitian Ex Post Facto. 1-8.

Yani, N. (2017). Upaya Peningkatan Hasil Belajar Siswa dengan Model Pembelajaran Kooperatif Tipe Investigasi Kelompok Pada Mata Pelajaran Fiqih Materi Pokok Shalat Jumat di Kelas VII di MTS Al- Hasanah Medan. 2-4. 